\title{
Giant colloid cyst of the third ventricle: challenges in management
}

\author{
Amit Agrawal $^{1 *}$, Vissa Santhi ${ }^{2}$ and Reddy V. Umamaheswara ${ }^{3}$
}

\begin{abstract}
Background: Giant colloid cysts (size $>3 \mathrm{~cm}$ ) are very rare with only few reported cases in the literature.

Case presentation: We report a case of 44 year female who presented with features of raised intracranial pressure, memory and gait disturbances. CT and MR imaging showed a large colloid cyst at foramen of Monro leading to obstructive hydrocephalus. The patient underwent right interhemispheric transcallosal-transforaminal approach and complete excision of the cyst.

Conclusions: For a large size of colloid cyst complete surgical excision is recommended. However deep midline location, proximity to the vital structures and giant size of the lesions make surrounding vital structures vulnerable for injury.
\end{abstract}

Keywords: Colloid cyst, Giant, Intracranial tumor

\section{Background}

Intracranial colloid cysts usually present as incidental findings on neuroimaging $[1,2]$. Colloid cysts are of tremendous interest as they are of benign nature, are surgically challenging to manage as these are deeply located, and have an excellent prognosis when diagnosed early and totally excised [3]. Usually the size of the colloid cysts range from range from $0.3-4.0 \mathrm{~cm}$ in size (mean $1.5 \mathrm{~cm}$ ) [4-7]. Giant colloid cysts $($ size $>3 \mathrm{~cm}$ ) are very rare with only few reported cases in the literature [8-12]. We present a case of giant colloid cyst of the anterior third ventricle which was managed successfully.

\section{Case report}

A 44 year female presented with the history off and on mild headache relieved by medication of 3 months duration. She had one episode of low grade fever 15 days back. She also developed difficulty of speech 15 days, and difficulty in walking 15 days duration. She also had memory loss and urinary incontinence of similar duration. Her general and systemic examination was unremarkable. Fundus showed bilateral papilloedema. Cranial nerves were normal. Neurological examination showed mild memory

\footnotetext{
* Correspondence: dramitagrawal@gmail.com

${ }^{1}$ Department of Neurosurgery, Narayana Medical College Hospital,

Chinthareddypalem, Nellore, Andhra Pradesh, India

Full list of author information is available at the end of the article
}

disturbances and gait disturbances. Motor and sensory examination was normal. Blood investigations including coagulation profile were normal. Axial CT precontrast images showed a well-defined $5 \times 5 \mathrm{~cm}$ size, hyperattenuating cystic lesion in the region of foramen of Monro leading to obstructive hydrocephalus. There was no enhancement after contrast administration (Fig. 1). Axial MRI images confirmed the cystic nature of the lesion, diffusion weighted sequence showed no restriction in the cyst and on post contrast images there was no enhancement of the cyst (Fig. 2). MRI saggital T2 and post contrast images showed the cranio-caudal extension of the lesion. Inferiorly lesion was buckling the optic chiasma and tegmentum of midbrain. Coronal FLAIR images showed mild hydrocephalus and minimal periventricular ooze (Fig. 3). Based on the imaging findings a diagnosis of giant colloid cyst was suspected. The patient underwent right fronto-parietal parasagittal large craniotomy midline interhemispheric transcallosal-transforaminal approach and complete excision of the cyst. Histopathology confirmed the diagnosis of colloid cyst (Fig. 4). Post-operative CT scan showed complete excision of the cyst with mid intraventventricular hemorrhage (Fig. 5). At 1 year the patient is doing well at follow up except mild memory disturbances. 


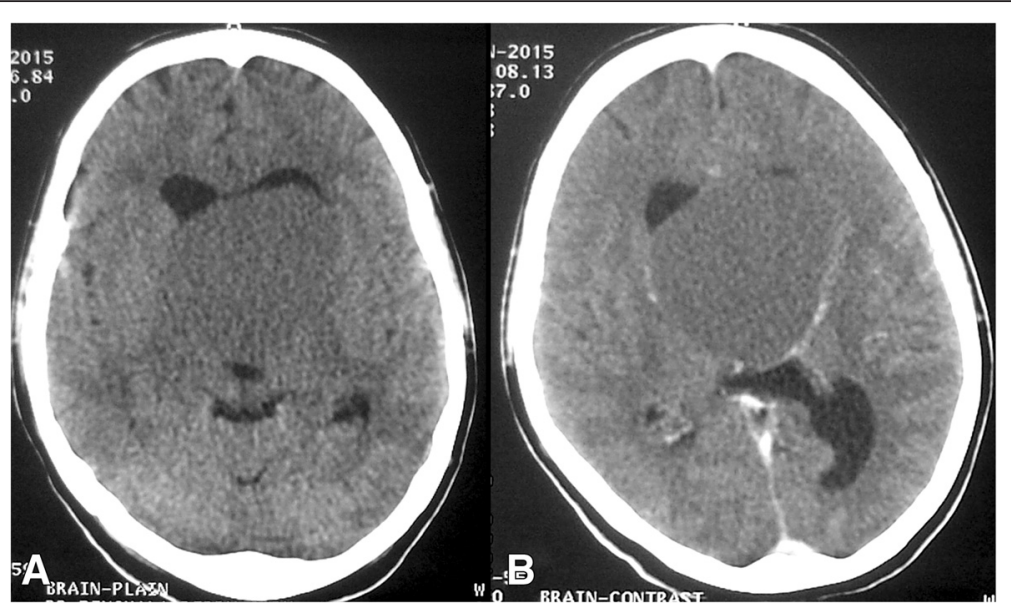

Fig. 1 Axial CT images pre-contrast (a) showing well defined hyper-attenuating cystic lesion in the region of foramen of monro and on post contrast image (b) there is no enhancement. Mild dilatation of frontal horns is also noted

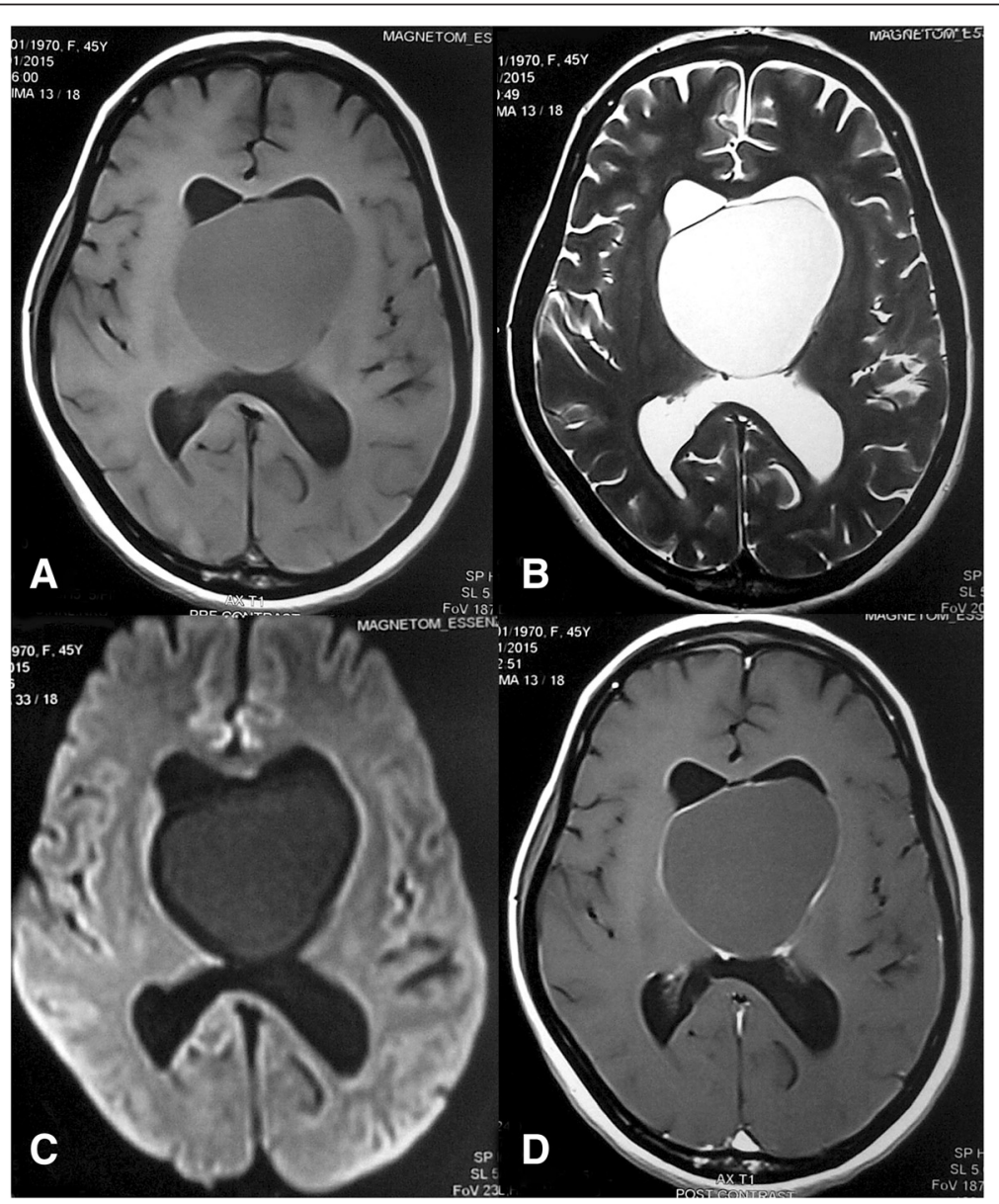

Fig. 2 Axial MRI images (a, b) confirming the cystic nature of the lesion. On diffusion sequence (c) there is no restriction in the cystic lesion. Post contrast images (d) showing no enhancement within the cystic lesion 


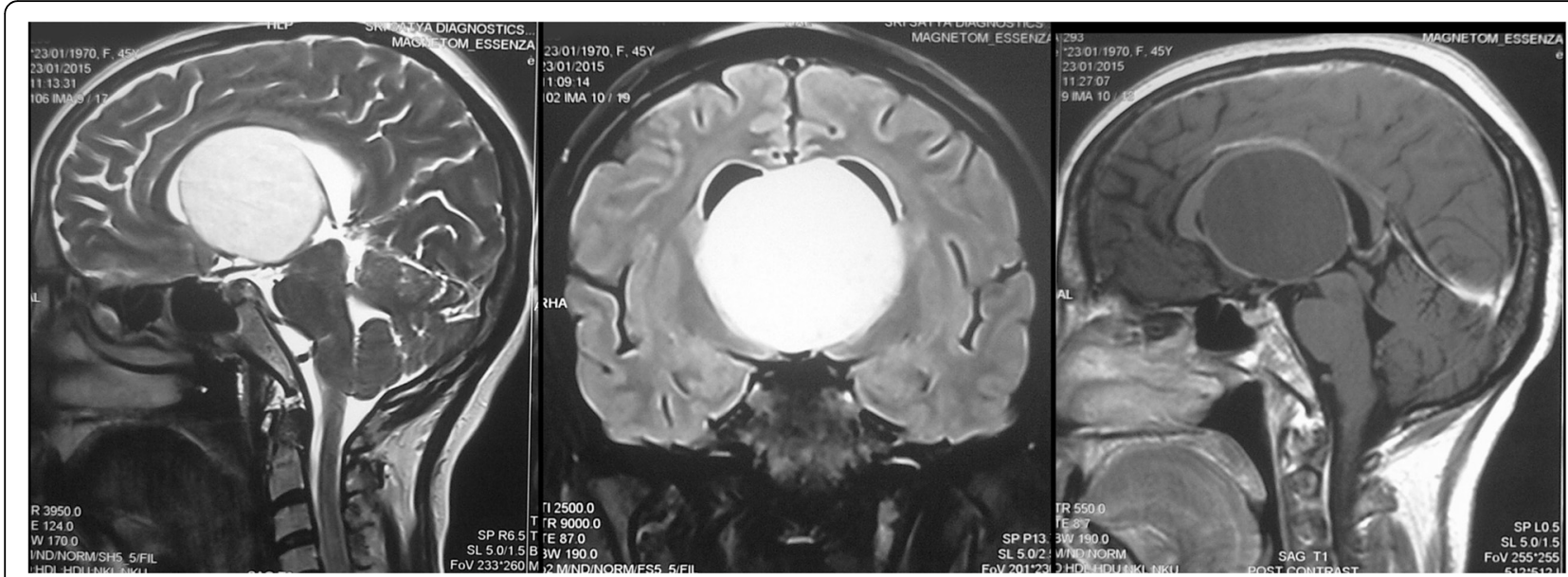

Fig. 3 Saggital T2 (Left and Middle image) and post contrast (Right image) demonstrating the cranio-caudal extension of the lesion. Inferiorly lesion is buckling the optic chiasma and tegmentum of midbrain. Coronal FLAIR images demonstrating the mild hydrocephalus, minimal periventricular ooze and relation with third ventricle

\section{Discussion}

Although colloid cysts are histologically benign in nature, their midline location can cause obstruction of the foramen of Monro resulting in obstructive hydrocephalus $[1,2,4]$. Even smaller lesions have been reported to be associated with sudden death [5, 13-16]. Clinically colloid cysts can be asymptomatic (incidental finding on neuroimaging), seizures, can present with features of raised intracranial pressure (headache, vomiting, and papilledema) due to the development of hydrocephalus or can cause progressive memory loss thus requiring surgical intervention $[1,2,11,14,16,17]$. CT scan with contrast administration can be the initial modality of investigation, however MRI will provide greater details regarding, size, relationship with the surrounding structures and nature of the cyst. [4, 5, 18-20] Imaging appearance depend on the composition and density of the cysts contents (quantity of cholesterol and protein) $[5,19,20]$. Characteristically colloid cyst appear as well- delineated hyperdense lesion at the foramen of Monro Usually the colloid cyst does not enhance on CT as well as on MRI [2, 5, 18-21]. Larger lesions can be associated with calcification in the cyst wall [11]. Most of the colloid cysts are hyperintense on T1weighted MR images and on T2-weighted images becomes hyperintense in relation to brain parenchyma [5, 18-20]. Although on T2-weighted MR images, the appearance can range from hypointense to hyperintense, and the cyst can be homogeneous or heterogeneous [22]. Although on neuroimaging a diagnosis of colloid can be suspected, however histopathology will confirm the diagnosis $[1,18,19]$. The management options for colloid cysts include stereotactic aspiration, endoscopic fenestration and microsurgical excision $[15,20,23-25]$. Because of the large size of the lesion, complete surgical excision by transcortical/transventricular approach is preferred modality of management for giant size lesions $[2,11]$.

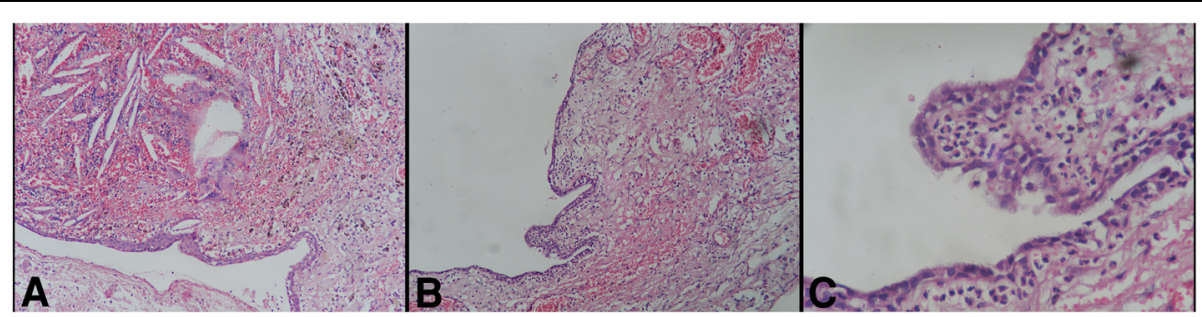

Fig. 4 a Cyst lined by squamous epithelium. Underlying tissue shows areas of hemorrhages, cholesterol clefts, foreign body giant cells and hemosiderin laden macrophages(H\&E,X100), (b) Cyst lined by cuboidal lining epithelium. Underlying tissue shows mixed inflammatory cells and congested blood vessels (H\&E,X100) and (c) Cyst lined by cuboidal lining epithelium. Subepithelial tissue shows acute inflammatory cells and congested blood vessels ( $H \& E, X 400)$ 


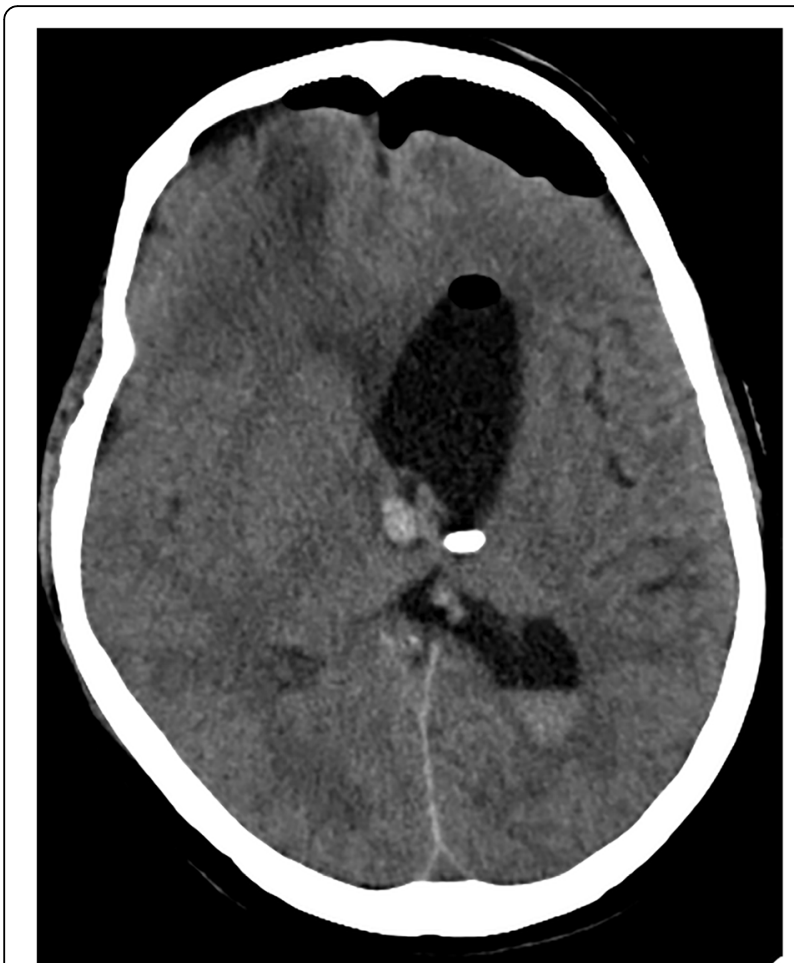

Fig. 5 Post-operative CT image showing complete excision of the lesion with mild intraventricular hemorrhage

\section{Conclusions}

It has been suggested that neuroendoscopy is a safer and more effective approach (shorter operating time and hospital stay) than transcallosal craniotomy and can be considered as the first line of treatment [26]. However neuroendscopy can be more challenging and demanding to manage such a large lesions. Deep midline location, proximity to the vital structures and giant size of the lesions can predispose surrounding vital structures vulnerable for injury [1, 23, 24, 27, 28]. Injury to the vital structures can lead to transient or permanent memory loss, motor deficits, seizures, hemorrhage, hydrocephalus and infection [23, 24].

\section{Consent}

We obtained written permission from the patient to publish this case report.

\section{Abbreviations}

CT: Computerized Tomography; MRI: Magnetic Resonance Imaging; FLAIR: Fluid attenuation inversion recovery.

\section{Competing interests}

The authors declare that they have no competing interests.

\section{Authors' contributions}

All authors read and approved the final manuscript.

\section{Author details}

'Department of Neurosurgery, Narayana Medical College Hospital, Chinthareddypalem, Nellore, Andhra Pradesh, India. ${ }^{2}$ Department of
Pathology, Narayana Medical College Hospital, Chinthareddypalem, Nellore, Andhra Pradesh, India. ${ }^{3}$ Department of Radiology, Narayana Medical College Hospital, Chinthareddypalem, Nellore, Andhra Pradesh, India.

Received: 30 November 2015 Accepted: 18 February 2016 Published online: 28 April 2016

\section{References}

1. Woodley-Cook J, Martinez JL, Kapadia A, Munoz DG, Bharatha A, Spears J. Neurosurgical management of a giant colloid cyst with atypical clinical and radiological presentation. J Neurosurg. 2014;121:1185-8.

2. Ravnik J, Bunc G, Grcar A, Zunic M, Velnar T. Colloid cysts of the third ventricle exhibit various clinical presentation: a review of three cases. Bosn J Basic Med Sci. 2014;14:132-5

3. Rao BH, Satyavaraprasad K, Rajiv PK, Phaneeswar T. Giant Colloid Cyst of Third Ventricle: A Rare Case Report. Int J Sci Stud. 2015;3(6):247-250.

4. Mamourian AC, Cromwell LD, Harbaugh RE. Colloid cyst of the third ventricle: sometimes more conspicuous on CT than MR. AJNR Am J Neuroradiol. 1998;19:875-8.

5. Armao D, Castillo M, Chen H, Kwock L. Colloid cyst of the third ventricle: imaging-pathologic correlation. AJNR Am J Neuroradiol. 2000;21:1470-7.

6. Osborn A. Miscellaneous tumors, cysts, and metastases. Diagnostic neuroradiology. St Louis: Mosby; 1994. p. 631-49.

7. Osborn AG, Maack J. Diagnostic neuroradiology. St. Louis: Mosby; 1994.

8. Kasliwal MK, Kiran S, Agrawal D, Sharma BS. Giant colloid cyst in a child. Pediatr Neurosurg. 2007;43:442-3.

9. Yamanaka K, Iwai Y, Nakajima H, Kobayashi $Y$, Inoue T. Multiple remote brain hemorrhages after removal of a giant colloid cyst of the third ventricle-case report. Neurol Med Chir. 1998;38:24-7.

10. Sambasivan M, Padmanabhan S, Sambasivan M. Large colloid cyst of the anterior third ventricle associated with calcification in the cyst wall. Neurol India. 2010:58:330-1.

11. Yuceer N, Baskaya M, Gokalp HZ. Huge colloid cyst of the third ventricle associated with calcification in the cyst wall. Neurosurg Rev. 1996;19:131-3.

12. Hamlat A, Casallo-Quiliano C, Saikali S, Adn M, Brassier G. Huge colloid cyst: case report and review of unusual forms. Acta Neurochir. 2004;146:397-401. discussion 401.

13. Carrasco R, Pascual JM, Medina-López D, Burdaspal-Moratilla A. Acute hemorrhage in a colloid cyst of the third ventricle: A rare cause of sudden deterioration. Surg Neurol Int. 2012;3:24.

14. Roldán-Valadez E, Hernández-Martínez P, Elizalde-Acosta I, Osorio-Peralta S. Colloid cyst of the third ventricle: case description and survey of the literature. Rev Neurol. 2003;36:833-6.

15. Silva D, Matis G, Chrysou O, et al. Sudden death in a patient with a third ventricle colloid cyst. Arq Neuropsiquiatr. 2012;70:311.

16. Turillazzi E, Bello S, Neri M, Riezzo I, Fineschi V. Colloid cyst of the third ventricle, hypothalamus, and heart: a dangerous link for sudden death. Diagn Pathol. 2012;7:144.

17. Pollock BE, Huston J. Natural history of asymptomatic colloid cysts of the third ventricle. J Neurosurg. 1999;91:364-9.

18. Kimura H, Fukushima T, Ohta T, et al. A case of colloid cyst of the third ventricle. No Shinkei Geka Neurol Surg. 1988;16:1483-8.

19. Algin O, Ozmen E, Arslan H. Radiologic manifestations of colloid cysts: a pictorial essay. Can Assoc Radiol J. 2013;64:56-60.

20. El Khoury C, Brugières $P$, Decq $P$, et al. Colloid cysts of the third ventricle: are MR imaging patterns predictive of difficulty with percutaneous treatment? AJNR Am J Neuroradiol. 2000;21:489-92.

21. Maeder PP, Holtås SL, Basibüyük LN, Salford LG, Tapper UA, Brun A. Colloid cysts of the third ventricle: correlation of MR and CT findings with histology and chemical analysis. AJR Am J Roentgenol. 1990;155:135-41.

22. Wilms G, Marchal G, Van Hecke P, et al. Colloid cysts of the third ventricle: MR findings. J Comput Assist Tomogr. 1990;14:527-31.

23. Desai Kl, Nadkarni TD, Muzumdar DP, Goel AH. Surgical management of colloid cyst of the third ventricle-a study of 105 cases. Surg Neurol. 2002;57:295-302. discussion 302.

24. Grondin RT, Hader W, MacRae ME, Hamilton MG. Endoscopic versus microsurgical resection of third ventricle colloid cysts. Can J Neurol Sci. 2007:34:197-207.

25. Kapu R, Pande A, Vasudevan MC, Ramamurthi R. Giant colloid cyst of third ventricle with microhemorrhages causing neurological deterioration: a very rare presentation. Neurol India. 2012;60:557-8. 
26. Horn EM, Feiz-Erfan I, Bristol RE, et al. Treatment options for third ventricular colloid cysts: comparison of open microsurgical versus endoscopic resection. Neurosurgery. 2007;60:613-8. discussion 618-620.

27. Levine NB, Miller MN, Crone KR. Endoscopic resection of colloid cysts: indications, technique, and results during a 13-year period. Minim Invasive Neurosurg. 2007;50:313-7.

28. de Witt Hamer PC, Verstegen MJT, De Haan RJ, et al. High risk of acute deterioration in patients harboring symptomatic colloid cysts of the third ventricle. J Neurosurg. 2002;96:1041-5.

Submit your next manuscript to BioMed Central and we will help you at every step:

- We accept pre-submission inquiries

- Our selector tool helps you to find the most relevant journal

- We provide round the clock customer support

- Convenient online submission

- Thorough peer review

- Inclusion in PubMed and all major indexing services

- Maximum visibility for your research

Submit your manuscript at www.biomedcentral.com/submit 